\title{
O DESAFIO DO CRESCIMENTO ECONÔMICO ENDÓGENO
}

\author{
Eunice de Andrade Stenger $\left({ }^{1}\right)$
}

Toda afirmação sobre o mundo real repousa de alguma forma sobre algum tipo de previsão sobre o futuro, fundada numa reflexão sobre o que aconteceu no passado. O presente se torna um eterno "déjà vu" quando conhecemos a história. A história é ferramenta importante também no mundo da gestão, prova disto é a muito oportuna e esperada segunda edição do livro de Domingos Giroletti ("Fábrica: Convento e Disciplina", Editora UNB, 2002).

A obra remete-nos às raízes do processo de industrialização (tardia) brasileira, tomando por base a experiência da indústria têxtil do centro e norte de Minas Gerais nos finais do século XIX e início do século XX. São as empreitadas de um empresariado que se lança na tentativa da formação de uma massa de operários em um país recentemente saído da escravidão. Transição difícil para a modernidade do capitalismo em uma sociedade que se defrontava com o desafio de fazer, em poucos anos, uma passagem à ordem burguesa, ordem que levara séculos para se consolidar na Europa.

A produção têxtil mineira, discutida por Giroletti, se movia por um projeto amplo e profundo de construção de uma "nova Inglaterra", algo como uma revolução industrial em Minas. O livro agrega aspectos de enorme originalidade quando sublinha o caráter de uma burguesia empreendedora, ainda que emperrada pelos resquícios de uma mentalidade escravocrata, que se esforçava na implantação de indústrias, na modernização de outros aspectos da economia e em requalificar o trabalhador nacional, transformando-o em operário industrial no sentido amplo (técnico, disciplinar e ideológico).

Efetivamente, constata-se nas cartas e relatos dos empresários debutantes um enorme desconsolo com a qualidade da mão-de-obra nacional disponível no período. Como agravante, os empresários eram, eles mesmos, limitados em sua percepção do que poderia ser esse mundo industrial. Neste sentido a própria relação contratual dependia desta evolução das relações industriais, que ainda não estavam consolidadas.

Aqui, a admissão num emprego era lida como um ato de caridade ou favor do patrão. Contratos de trabalho ainda em forma precária. Cartas de apresentação chegavam aos patrões como súplicas por um emprego, típicas de uma sociedade em que trabalhar era humilhante porque atributo do negro.

Os resquícios de uma ordem antiga persistiam. Daí, porque, a excessiva relevância de quem indica em detrimento do indicado. Maior importância tinha quem apresentava o candidato ao posto de trabalho e pouca atenção se dava, de fato, às capacidades efetivas do candidato. Não restam ainda hoje no Brasil muitos destes traços?

\footnotetext{
${ }^{1}$ Professora Universitária, Doutoranda pela Universidade de Paris I/ Panthéon/ Sorbonne.- Paris e Pesquisadora do Laboratório Georges Friedman, França.
} 
Na transição de um Brasil agrário para um outro industrial, apareciam mesclados os contornos da uma gestão empresarial movida por uma relação contraditória entre duas mentalidades, uma moderna e empreendedora e a outra escravocrata e paternalista.

Tudo isto nos obriga a reconhecer quão duros foram os passos palmilhados na nossa constituição como sociedade de trabalho e a luta pela industrialização do pais, processo ainda em andamento como nos indica Giroletti.

Aqui nas Gerais, a produção, assim como grande parte da dinâmica de acumulação de capital, baseava-se no mercado interno e no uso da mão-de-obra "nacional". O técnico empregado das primeiras fábricas, tinha, a princípio, origem inglesa. Mas, foi sendo, progressivamente, substituído pelo trabalhador nacional. Isto implicava, certamente, em um reordenamento na vida do trabalhador rural ou de origem escrava.

Que esforços deveriam ser feitos para que se consolidasse a revolução industrial em Minas que haveria de nos transformar numa "nova Inglaterra"! Sim, pois, não se tratava apenas de se qualificar tecnicamente a mão-de-obra, era necessário que esta fosse moldada por uma nova ética que valorizasse o trabalho e fosse voltada à produção que se queria "moderna".

Esta transformação dependia de fato de aspectos múltiplos que a corrida contra o tempo iria transformar numa nova modalidade de "revolução burguesa" (Florestan . Fernandes, A Revolução Burguesa no Brasil, Zahar, 1974), a busca de algo semelhante àquilo que Weber denominou de constituição da "Ética Protestante e o Espírito do Capitalismo", no seu célebre livro que leva este título.

Incumbiu-se o novo empresariado mineiro de adequar a mão-de-obra aos conteúdos de disciplina, ritmo e destreza da indústria moderna. A gestão industrial, à época, não era apenas do trabalho, mas, envolvia sempre e, ao mesmo tempo, as dimensões social e familiar. O disciplinamento ia além dos muros da fábrica, incluía até enclausuramento de mulheres-operárias, órfãs, jovens e viúvas.

A presença das casas paroquiais, de conventos ou de instituições semelhantes já fora destacada pela literatura que trata da revolução industrial na Europa. $O$ registro da presença de conventos na industrialização mineira e brasileira se deve ao livro do Professor Giroletti. O convento, como lugar de moradia e de controle das jovens operárias, é uma forma de domínio extra-fábrica.

Tipo semelhante de controle estendia-se a todos os operários que viviam nas vilas operárias em casas de propriedade dos industriais e dependendo em tudo dos serviços por eles oferecidos. $\mathrm{O}$ controle ia das normas de conduta social às manifestações da sexualidade e da sociabilidade. Tratava-se, afinal, de uma política industrial que ia além dos limites da fábrica.

Finalmente, centrar no argumento da obra - "Fábrica: Convento e Disciplina" - é sublinhar que, a despeito de tudo, os primórdios da gestão empresarial modernizante em Minas ali se delineara. A urgência na qualificação dos trabalhadores nacionais e de sua inserção na indústria e sociedade industrial se justificava como estratégia para um processo de desenvolvimento nacional endógeno. Em tempos de crise de inserção social como nos dias atuais, o livro de Giroletti traz ao presente aspectos de um período de difícil transição no qual os empresários de Minas souberam apostar no desenvolvimento industrial do Estado, valorizando o trabalhador nacional, numa luta ainda inconclusa, voltada à consolidação de um Brasil para os brasileiros. Giroletti nos remete assim ao questionamento essencial: Não seria desta disposição que o Brasil estaria precisando neste momento para consolidar o "espetáculo de crescimento" que o País necessita e aspira? 